\title{
PATENT RIGHTS AND TECHNICAL INFORMATION IN THE MILITARY ASSISTANCE PROGRAM
}

\author{
Robert S. Pasley* and John TeSellet
}

\section{INTRODUCTION}

The purpose of this article is to review some of the problems involving patent rights, technical information, and other kinds of proprietary data, which have arisen in connection with United States government contracting abroad, particularly under the Mutual Security Program. At the outset, some definitions and explanations will be in order. These will be followed by a brief history of the problem since World War II. The main part of the article will then be devoted to (a) an explanation of the applicable statutes and regulations, the international agreements in effect, and the administrative arrangements which have been devised; (b) a review of the judicial rulings in the area; and (c) an analysis of some typical contractual arrangements and of a few of the problems which have arisen thereunder. In conclusion, an attempt will be made to appraise the effect of current policies on (i) United States contracting activities, (ii) United States contractors, (iii) international organizations and their members, (iv) foreign contractors and business enterprises, and (v) the Mutual Security Program as a whole.

I

\section{Background of the Problem}

\section{A. The Mutual Security Program}

The Mutual Security Program (MSP) is now officially called the United States Foreign Assistance Program. It had its genesis in the Mutual Defense Assistance Program of $1949,{ }^{1}$ although it can be traced back further to the Truman Doctrine of

* A.B. 1933, Princeton University; LL.B. 1936, Cornell University. Professor of Law, Cornell University. Member of the New York and Federal bars. Contributor to legal periodicals in procurement and other fields.

A substantial portion of the research for this article was done under a Ford Foundation Fellowship, in Washington, D.C. and Paris, France, and the financial assistance of the Foundation is gratefully acknowledged. The opinions and conclusions presented hercin are, however, those of the authors and do not necessarily represent the views of the Ford Foundation or of any department or agency of the U.S. government.

† B.M.E. 1947, University of Florida; LL.B. 195I, University of Pennsylvania; LL.M. 1957, George Washington University. Member of the Florida and District of Columbia bars. Currently on the faculty of The Judge Advocate General's School, U.S. Army. From 1960 to I963, Patent Advisor, U.S. Mission to NATO, Paris, France. Author, Authorization or Consent to Infringe Patents in Production FOR THE GOVERNMENT (1958).

${ }^{2}$ This program was authorized by the Mutual Defense Assistance Act of 1949, ch. 626, 63 ST^r. 7r4.

a Aid to Greece and Turkey was authorized under the Truman Doctrine by the Act of May 22, x947, ch. 8I, 6r STAT. xo3. 
I947 $7^{2}$ and the Marshall Plan for the rehabilitation of war-torn Europe, ${ }^{3}$ and still further back to the Lend-Lease Program of World War II. ${ }^{4}$ It is currently authorized by the Foreign Assistance Act of $196 \mathrm{r}$, as amended, ${ }^{5}$ and specifically by part II thereof. ${ }^{\circ}$ The purpose of the latter, as stated by Congress, is to supplement the efforts of the United Nations to achieve international peace and security by authorizing "measures in the common defense against internal and external aggression, including the furnishing of military assistance, upon request, to friendly countries and international organizations."

The Military Assistance Program (MAP) is authorized by chapter two of part two of the act, and specifically by section $503 .^{\circ}$ As spelled out in the latter, it may take various forms, of which two are important for our purposes:

(a) acquiring and providing defense articles and services; and

(b) making financial contributions to multilateral programs for acquiring or constructing defense facilities in foreign countries.

In its simplest form, military assistance means procuring items domestically or abroad and furnishing them to friendly foreign countries or international organizations. When such items are acquired abroad, the process is known as "offshore procurement" or, more specifically, "military assistance offshore procurement" (MAP-OSP). (Another type of offshore procurement, which will not especially concern us here, is that undertaken for the direct needs of the United States forces, and is known as DOD-OSP.)

Offshore procurement played an important role in the early days of the military assistance program. ${ }^{8}$ It has been overshadowed in recent years, however, by more complex arrangements, of which the Mutual Weapons Development Program (MWDP) and the Weapons Production Program (WPP) are the most significant for our purposes. Under the former, now virtually completed, technical and financial aid was rendered to members of the North Atlantic Treaty Organization (NATO) for research in and the development of new military weapons and devices deemed necessary for joint defense. The latter involves production programs, undertaken on a cooperative basis by several NATO nations, drawing upon the results of American and foreign investment in military research and development. It finds its sanction in the following language of section 502 of the act:

... the Congress welcomes the steps which have been taken to promote multilateral programs of coordinated procurement, research, development, and production of defense

s The Marshall Plan was implemented by the Economic Cooperation Act of 1948, 62 STAт. 137. See Surrey,The Economic Cooperation Act of 1948, 36 Calif. L. Rev. 509 (1948).

55 STAT. 3 I (I94I), as amended, 22 U.S.C. $\$ \$ 4 I-423$ (1958).

- 75 STAT. 424 (I96I), as amended, 22 U.S.C. $\$ \$ 2151-2406$ (Supp. IV, I963) [hereinafter sometimes cited as "the act"].

75 STAT. 434 (I96I), as amended, 22 U.S.C. $\$ \$ 2301-23$ I9 (Supp. IV, I963).

75 STAT. 435 (I96r), 22 U.S.C. \$23rr (Supp. IV, I963).

${ }^{8}$ See Pasley, Offshore Procurement, Mil. L. Rev., Oct. I962 (DA Pam 27-100-I8), 55, at 56-59. 
articles and urges that such programs be expanded to the fullest extent possible to further the defense of the North Atlantic Area. 9

and its general authorization in section 503 of the act, summarized above. ${ }^{10}$

\section{B. Patent Rights and Technical Information}

A moment's reflection will bring home the fact that any program such as outlined above will bristle with problems in the industrial property area. Before launching into these, however, it might be desirable to define some of the terms used. (Although we shall limit ourselves to United States terminology, it might be remarked parenthetically that one of the great difficulties has been the lack of a common terminology and understanding of terms as among patent specialists of the various countries.)

I. Patents; Patent Applications; Patent Rights. The terms "patents" and "patent applications" are used in their ordinary statutory sense. "Patent rights" mean rights arising under patents or patent applications.

2. Invention; Information. Section 506(a) of the Mutual Security Act of $1954^{11}$ defined "invention" to mean "an invention or discovery covered by a patent issued by the United States," and "information" to mean "information originated by or peculiarly within the knowledge of the owner thereof and those in privity with him, which is not available to the public and is subject to protection as property under recognized legal principles." While these definitions are not carried over, as such, into the corresponding section 606 of the current act, that section by its terms applies to (i) "an invention or discovery covered by a patent issued by the United States government" and to (ii) "information, which is ... protected by law."12

3. Technical Information. The Model Interchange Patent Agreement ${ }^{13}$ defines "technical information" as meaning "information originated by or peculiarly within the knowledge of the owner thereof and those in privity with him and not available to the public."14 Some of the actual agreements, based on this Model, modify this language in minor respects.

4. Proprietary Data. The term "proprietary data" is defined in the Armed Services Procurement Regulation (ASPR) as meaning "data providing information concerning the details of a contractor's secrets of manufacture, such as may be contained in but not limited to his manufacturing methods or processes, treatment and chemical composition of materials, plant layout and tooling, to the extent that such information is not disclosed by inspection or analysis of the product itself and

${ }^{7} 75$ STAT. 435 (1961), 22 U.S.C. $\$ 2301$ (Supp. IV, I963).

${ }^{10}$ Supra note 7.

${ }^{11} 68$ STAT. 852 (1954).

1275 STAT. 440 (196I), 22 U.S.C. $\$ 2356$ (a) (Supp. IV, I963).

${ }^{13}$ See infra, pp. $572-73$.

${ }^{14}$ The text of a "Basic Model Agreement to Facilitate the Interchange of Patent Rights and Technical Information for Defense Purposes" is set forth in Patent and Technical Information Agreements, a Study of the Subcommittee on Patents, Trademarks, and Copyrights of the Senate Committee on the Judiciary, 86th Cong., 2d Sess., pursuant to S. Res. 240, Study No. 24, Exhibit A, at 31-46 (1960). The definition quoted is in article VIII, id. at 43. 
to the extent that the contractor has protected such information from unrestricted use by others." 15

5. Trade Secrets. Reference may be made to the elaborate definition, and examples, of the term "trade secrets," found in the Restatement of Torts. ${ }^{16}$

Of course, unilateral definitions such as those found in ASPR or the Restatement of Torts are not necessarily binding in international dealings, but they are included here as illustrative of the types of interests which are involved.

\section{II}

\section{History and Background}

The international interchange of patent rights and technical information, and the legal problems attendant thereon, first came to the fore during World War II under the Lend-Lease program. The history of that experience, and of the experiences under the Mutual Security and Military Assistance Programs which followed, down to the year 1958 , has been recounted in detail by Professor Michael H. Cardozo in a study prepared for the Subcommittee on Patents, Trademarks, and Copyrights of the Senate Committee on the Judiciary. ${ }^{17}$ Professor Cardozo's study should be read for a complete history of this interesting experiment in international cooperation, but it may be summarized briefly as follows.

Under Lend-Lease, the two principal problems faced were (I) how to induce private owners to release their inventions and technical information for use by the governments concerned, and (2) how to compensate such owners for their cooperation. It was soon realized that information about inventions alone was not enough, without the attendant "know-how." Even though the latter might not itself be patented, or even patentable, owners were reluctant to release it without compensation and without some advance assurance of the use to which it would be put. At the same time, the government of one country was understandably reluctant to compensate the nationals of another for license rights or technical information needed for the mutual defense of both. Wherever possible, therefore, a program of free licensing on the governmental level was worked out, each government assuming the obligation to compensate its own nationals. In imposing restrictions on further use of the information thus obtained, a balance had to be sought between unjustified extensions of monopolies on the one hand, and confiscatory practices on the other. ${ }^{18}$

The first substantial interchange of technical and scientific information took place between the British and Americans in 1940. Some of the most important wartime secrets, including those relating to anti-submarine and anti-aircraft devices and

\footnotetext{
${ }^{15}$ Armed Services Procurement Regulation [hereinafter cited as ASPR], I9-20x(b), 32 C.F.R. \$ 9.20I (b) (I96I), 3 CCH Gov'T CoNT. REP. I 33,046 (r96I).

${ }_{10}{ }_{4}$ Restatement, ToRTs, $\$ 757$, comment $b$ (I939).

${ }^{17}$ Exchange of Patent Rights and Technical Information under Mutual Atd Programs, A Study of the Subcommittee on Patents, Trademarks, and Copyrights of the Senate Committee on the Judiciary, 85 th Cong., 2d Sess., pursuant to S. Res. 236, Study No. 1o (1958).

${ }^{18}$ Id. at 2-3.
} 
methods, radar, bombsights, and other scientific discoveries were made mutually available. $^{19}$ In addition, arrangements were made to enable one nation to manufacture products of the other (for example, Rolls-Royce engines for incorporation in American aircraft), with suitable provisions for indemnification of claims made by private owners. ${ }^{20}$

In 1942 the British and United States governments entered into a Patent Interchange Agreement, which was amended in 1946. Under this agreement, a procedure was established whereby each government would facilitate procurement for the other of the right to make and use inventions or other legally protected processes, the cost of such procurement from the nationals of each country to be borne by that country. Each government undertook to gather and make available unpatented technical information needed by the other. A joint committee of representatives of the two governments was established, which functioned from 1943 to $1946^{21}$

The greatest value of this agreement, in Professor Cardozo's opinion, lay not so much in the concrete accomplishments thereunder as in the fact that it made possible the establishment of agreed terms for arranging patent licenses, the payment of royalties, and so forth, and provided a forum for free discussion of these matters and a clearing house for requisitions filed by each side for licenses to be obtained from nationals of the other. ${ }^{22}$ The most difficult problems, as might be anticipated, related to unpatented technical information, as opposed to patented inventions proper. Despite the many difficulties which arose, however, the free flow of information was not substantially impeded. ${ }^{23}$

At the end of the war the pattern was generally adopted, following the U.S.-U.K. agreement, of each nation agreeing to pay the claims of its own nationals for the use of their inventions by other nations. Since more such claims were asserted by foreign nationals than by Americans, this constituted a form of reverse lend-lease. ${ }^{24}$

This World War II history was the prelude to the problems which were to arise under the Mutual Security Program. When the latter program started, it was clear from experience that the existence of patents and the payment of royalties would not seriously impede production, but that the major difficulties would arise in connection with the dissemination of unpatented information. ${ }^{25}$ Moreover, the Military Assistance Program introduced new problems. Since standardization of equipment was sought, not only licensing, but instruction in the techniques of production, became necessary. ${ }^{2 B}$ New legal problems were presented, such as whether production under this program was "for the United States" under the statute barring claims for infringement and making a suit against the United States for damages the ex-

\footnotetext{
10 Id. at 4 .

${ }^{20}$ Id. at 5-7.

21 Id. at 7 -10.

${ }^{22} I d$. at IO-II.

${ }^{23} I d$. at II-I6.

21 . at $2 \mathrm{I}-22$.

${ }^{25}$ Id. at 23-24.

${ }^{20} \mathrm{Id}$. at 24 .
} 
clusive remedy. ${ }^{27}$ After two years of uncertainty, this point was clarified by a provision in the Mutual Security Act of 195I, the predecessor of section 606 of the current Act, which will be discussed below.

Another step taken under the Mutual Security Program was the negotiation of a series of international bilateral agreements on the interchange of patent rights and technical information for defense purposes, modeled after the U.S.-U.K. agreement of World War II. ${ }^{28}$ These will be explained in greater detail below. The first such agreement was signed with the United Kingdom in January $1953{ }^{29}$ and others followed in the course of the next few years, embracing ultimately most of the NATO countries and other nations as well..$^{30}$

All of these, however, were bilateral agreements with the United States. An attempt was therefore made to work out a multilateral agreement, analogous to the NATO Status of Forces Agreement, ${ }^{31}$ to which all the NATO countries could be parties. Such an agreement has been negotiated and entered into force on June r2, I $96 \mathrm{r},{ }^{32}$ but it is limited to the safeguarding of secrecy of military inventions for which patent applications have been made, and does not extend to the interchange of patent rights and technical information, as do the bilateral agreements mentioned above.

\section{III}

\section{Statutory Provisions, Patent Interchange Agreements, and Department of Defense Directive}

\section{A. Statutory Provisions}

The most important section of the act, for our purposes, is section 606, Patents and Technical Information. ${ }^{33}$ Briefly, this provides that whenever, in connection with the furnishing of assistance under the act, (i) a United States patented invention is used in the United States without authorization of the owner, or (ii) information protected by law and held by the United States subject to restrictions imposed by the owner is disclosed by the government or its agents in violation of such restrictions, the exclusive remedy of the owner is a suit against the government for reasonable compensation in a federal district court or the Court of Claims. In any such suit, the government may plead any defense that might be pleaded by a

${ }^{87} 62$ STAT. 94I (1948), as amended, 28 U.S.C. $\$ 1498$ (Supp. IV, 1963).

${ }^{28}$ Exchange of Patent Rights and Technical Information under Mutual aid Programs, op. cit. stipra note 17 , at 28-34.

${ }^{20}$ Interchange of Patent Rights and Technical Information, Jan. 19, 1953, T.I.A.S. No. 2773,4 U.S.T. \& O.I.A. I50 (1953).

${ }^{20}$ See Westerman, International Exchange of Patent Rights and Technical Information for Defense Purposes, 2I Fed. B.J. 152, at 153-54 (I96I).

${ }^{81}$ North Atlantic Treaty, June 15, x95I, T.I.A.S. No. 2846,4 U.S.T. \& O.I.A. 1792 (I95I). See Exchange of Patent Rights and Technical Information under Mutual Aid Programs, op. cit. supra note 17 , at 33-34; Robillard, Government Patent Administration, Policy and Organization, I PAT., T.M. AND Copyright J. of Res. AND Ed. 270, at $280-8$ I (T957).

sa Agreement for the Mutual Safeguarding of Secrecy of Inventions Relating to Defence and for Which Applications for Patents Have Been Made, T.I.A.S. No. 4672, I2 U.S.T. \& O.I.A. 43 (I960).

${ }^{33} 75$ STAT. 440 (I96I), 22 U.S.C. $\$ 2356$ (Supp. IV, 1963). 
private party in such an action. Any such claim may be settled administratively by the head of the government agency concerned. Within limits, government officers and employees are permitted to present such claims.

This section is the successor to section 5 I7 of the Mutual Security Act of $195^{{ }^{34}}$ and section 506 of the Act of $1954^{35}$ Its purpose is to make available in mutual security operations the same type of protection afforded government procurement in general by section 1498 of the Judiciary Code ${ }^{38}$ (substitution of a direct claim against the government for a patent infringement proceeding, thereby assuring continuity of production), and extension of this type of protection to information which is unpatented but entitled to legal protection.

\section{B. Patent Interchange Agreements}

The Mutual Defense Assistance Act of I949 directed that, before military assistance was furnished to any country, an agreement be made between the United States and that country concerning the terms and conditions of such assistance. ${ }^{37}$ Pursuant to this statutory mandate, the United States has entered into a series of Mutual Defense Assistance Agreements, covering such matters as the use of the assistance furnished, restrictions against further transfer, security, and, in general terms, patent claims, tax relief, diplomatic immunities, and so on. ${ }^{38}$ These overall agreements are supplemented by a series of special agreements on tax relief, offshore procurement, disposal of equipment, and the like. Our principal interest here is with the agreements to facilitate interchange of patent rights and technical information for defense purposes, ${ }^{39}$ called for short "Patent Interchange Agreements." These are explained in detail in a study prepared for the Subcommittee on Patents, Trademarks, and Copyrights of the Senate Committee on the Judiciary by the International Business Practices Division of the Department of State. ${ }^{40}$ Exhibit $A$ to this study sets forth the text of a "Basic Model Agreement" and indicates the differences (mostly minor) between the Model Agreement and the agreements actually concluded. ${ }^{41}$ By now, such agreements have been entered into with nearly all the NATO countries and several other nations as well.

In summary, these agreements provide as follows:

(A) Each government agrees to facilitate the use of patent rights and encourage the flow and use of privately owned technical information

(a) through the medium of existing commercial relationships between the owner and the user, and

${ }^{34} 65$ STAT. 382 (195I).

${ }^{35} 68$ STAT. 852 (r954).

${ }^{30} 62$ StaT. 94I (I948), as amended, 28 U.S.C. $\$ 1498$ (Supp. IV, I963).

${ }^{37}$ Mutual Defense Assistance Act of 1949, $\$ 402,63$ STAT. 717 (1949).

${ }^{38}$ See Pasley, Offshore Procurement, MIL. L. Rev., October 1962 (DA Pam. 27-100-18) 55, at 63.

${ }^{\text {so }}$ See Westerman, International Exchange of Patent Rights and Technical Information for Defense Purposes, 21 FED. B.J. 152, at 153-57 (1961); Robillard, Governmental Patent Administration, Policy and Organization, I Pat., T.M. AND Copyrught J. of Res, AND Ed. 270, at 280-8I (1957).

so Patent and Technical Information Agreements, op. cit. suprat note 14.

${ }^{41}$ Id. at $3 \mathrm{~T}-55$. 
(b) in the absence of such relationships, through the creation thereof by the owner and the user, subject to certain restrictions on classified information and subject to any applicable laws.

(B) When technical information is disclosed by one government to another for information only, and this is stipulated at the time, the recipient government shall treat the information in confidence and endeavor to prevent any prejudice to the rights of the owner to obtain patent protection or the like.

(C) When technical information made available by one government to another discloses an invention on which the patent or patent application is held in secrecy in the country of origin, similar treatment will be accorded to a patent application in the other country.

(D) (i) Where privately owned technical information, communicated by the owner to his government and disclosed by that government to the other government, is used or disclosed by the latter without the consent of the owner, and compensation is paid to the owner by his government, such payment shall be without prejudice to arrangements between the two governments on assumption as between them of liability therefor.

(ii) When technical information, made available by a national of one government to the other government at the latter's request, is subsequently used or disclosed for any purpose, the latter shall take whatever steps are possible under its law to provide compensation therefor to the owner.

(E) When one government has the right to license the use of an invention, and such invention is used by the other government for defense purposes, the latter shall be entitled to use it without cost, except to the extent that there may be liability to a private owner with established interests therein.

(F) Each government is to designate a representative to a Technical Property Committee, with designated functions relating to problems arising under the agreement, principally in the areas of consultation, negotiations, and recommendations.

(G) Each government will, on request and so far as practicable, furnish to the other all necessary information and assistance (i) to afford the owner of technical information which has been made available for defense purposes the opportunity to protect and preserve his rights therein, and (ii) to enable the other government to assess payments and awards arising out of the use of patent rights and technical information made available for defense purposes.

\section{DOD Directive 2000.3}

The Department of Defense policy on the international interchange for defense purposes of patent rights and technical information is set forth in DOD 2000.3 , issued 
March Ir, I959, and amended July $18,1961,{ }^{42}$ superseding an earlier directive issued in $1954^{43}$

The directive first recites the existence of patent interchange agreements with fourteen different countries, and summarizes the general purport of those agreements. It then recites that the United States representatives on the Technical Property Committees established by the agreements are
(a) in Europe, the Patent Advisor assigned to the Defense Staff of the U.S. Mis- sion to NATO and European Regional Organizations (USRO), in Paris, France;
(b) in Japan, the J-4, Hq., United States Forces, Japan, in Tokyo;
(c) in Australia, a member of the Office of Assistant General Counsel, Interna- tional Affairs, Office of the Secretary of Defense.

The directive then states the policy of the Department of Defense to encourage and facilitate international interchanges of patent rights and technical information to further the common defense of the United States and friendly nations. Certain principles are to be observed:

(a) Classified military information may be released only through government channels and consistently with the National Disclosure Policy (or as specifically approved in exceptional cases);

(b) Otherwise, commercial channels are to be used to the maximum extent feasible;

(c) Use of commercial channels for exportation of unclassified privately owned technical information relating to articles on the United States Munition List shall be subject to the regulations of the Secretary of State issued with respect thereto; ${ }^{44}$.

(d) Privately owned technical information may be released by Department of Defense agencies to foreign governments if

(i) the owner expressly consents; or

(ii) the United States has acquired, or is entitled to acquire, the information under circumstances which permit its release; or

(iii) the Secretary of a Military Department or his designee determine that (A) the exigencies of the situation do not allow time to obtain the consent of the owner; or

(B) the owner refuses consent but the best interests of the United States would be served by the release.

42 "International Interchange of Patent Rights and Technical Information," 32 C.F.R., Part 264 (I96I), as amended, $\$ 264.3$ (a), (b)(2) (Supp. I964); 2 CCH Gov'T Cont. Rep. I 29, 62I (rg6r).

${ }^{13}$ DOD Directive 2000.3, Technical Property Interchange Agreements, dated April 15, I954.

4. This is. required by $\S_{4}$ I4 of the Mutual Security Act of 1954,68 Stat. 848, as amended, 22 U.S.C. $\$ 1934$ (1958), as amended, $\$ 1934$ (d) (Supp. IV, 1963 ). The regulations of the Secretary of State issued pursuant to this section, including the United States Munitions List, are set forth in 22 C.F.R., part 121 (Supp. 1963). 
(e) Release by Department of Defense agencies of privately owned technical information shall normally be in two stages:

(i) release for information only;

(ii) permission for manufacture, or use, for defense purposes.

(f) All technical information released by Department of Defense agencies to a foreign government shall be marked with certain specified restrictive notices, designed to limit its uses to defense purposes and to give it the maximum degree of protection both from the standpoint of security and the property interests of the private owner (if any).

(g) When privately owned technical information is released, the owner shall be notified of the release, of the identity of the recipient (if not classified), of the fact that the recipient has been advised of the fact or possibility of private ownership, and of the restrictions to which the release is subject.

The directive concludes with a statement of the procedure to be followed in asserting and settling or compromising claims for compensation under section 606 of the act. ${ }^{45}$

\section{IV}

\section{Judicial Construction of Claims Statute}

There is a paucity of judicial opinions construing section 606 of the act ${ }^{46}$ and its predecessors. As a matter of fact, the few cases which have been reported were all decided under section 506 of the $1954 \mathrm{act}^{47}$ or section $5 \mathrm{I7}$ of the $195 \mathrm{I}$ act. ${ }^{48}$ Since, however, these provisions are basically similar, the construction given to the prior statutes is still relevant under the current act.

Ushakoff v. United States ${ }^{49}$ was an action brought under the $195^{1}$ act to recover reasonable compensation for allegedly unauthorized use of a patented invention in furtherance of the purpose of the Mutual Security Program. The government moved to dismiss and for summary judgment on the grounds that there had been no procurement of the patented devices under the Mutual Security Program and that none of said devices had been furnished or issued under that program. The Court denied the motion, ruling that defendant's allegations were conclusions only, which did not warrant dismissal or summary judgment; issues were raised which could only be decided after a trial. ${ }^{49 a}$

In Kaplan v. United States ${ }^{50}$ a similar question, presented under both the $195 \mathrm{I}$ and the 1954 acts, was given a more definite answer. Plaintiff alleged that the gov-

46 Supra pp. 57I-72.

1075 STAT. 440 (I96r), 22 U.S.C. $\$ 2356$ (Supp. IV, I963).

478 STAT. 852 (1954).

${ }^{48} 65$ STAT. 382 (I95I).

10120 F. Supp. 573 (D. Mass. I954).

doa Subsequently, plaintiff recovered compensation under section 1498 of the Judiciary Code. 327 F.2d 669, 140 U.S.P.Q. 34I (Ct. Cl. I964). No mention is made in the opinion of any claim under the Mutual Security Act.

${ }^{\text {ro }}{ }_{39}$ Ct. Cl. 682, I53 F. Supp. 787 (1957). 
ernment had, under various contracts with third parties, arranged for the manufacture and procurement of certain sleeping bags, that such manufacture involved the unauthorized use of plaintiff's patented invention, and that the sleeping bags were "packed for overseas shipment and use by friendly nations within the language, meaning, and content of the Mutual Security Acts, and by said friendly nations used for the purposes set forth in said Mutual Security Acts."

Plaintiff filed claims both under section 1498 of the Judiciary Code, ${ }^{51}$ which applies to government procurement generally, and under the Mutual Security Acts. On motion to dismiss, the Court of Claims sustained the allegations on the former claims but dismissed those on the latter. The contracts in question were made by the United States with United States manufacturers. There were no allegations that they were let on behalf of any foreign country, but only that the end product was shipped overseas and used by friendly foreign nations. Citing the legislative history of the statute, the court held that these allegations were not enough to invoke the jurisdiction conferred upon it by the Mutual Security Acts. Plaintiff's case fell squarely within section $I 498$ of the Judiciary Code and his rights were fully protected under that statute.

So far as patented inventions are concerned, this decision is not of great significance. The purpose of the provisions of the Mutual Security Act (now the Foreign Assistance Act) was to remove any doubt that the principle of section 1498 applied to mutual security procurement. If the case is already clearly covered by section 1498 , the supplemental provisions of the Mutual Security legislation add very little. True, minor differences exist:

(i) Under section 1498 plaintiff's only forum is the Court of Claims; he does not have the alternative of suing in a United States district court.

(ii) There is no provision in section 1498 for administrative settlement by the head of the department concerned, comparable to the provisions in section 606.

In the case of unpatented proprietary information, however, the case may be different. Section 606 of the Foreign Assistance Act, like its predecessors, affords 2 remedy here where none is given by section 1498 of the Judiciary Code. In this area, therefore, the metes and bounds of section 606 become important. It can be argued, however, that the restrictive rule of the Kaplan case, while capable of fairly simple application in the case of a patented invention which is "practiced within the United States" by a United States contractor, can have no such clear-cut application to the case of a disclosure of information by the United States. If, in fact, such disclosure is made at any stage in the course of carrying out the Mutual Security Program, section 606 by its own terms would seem to apply.

The most interesting case is Farrand Optical Co. v. United States,, 52 but, un-

${ }^{81} 62$ STAT. 941 (1948), as amended, 28 U.S.C. $\$ 1498$ (Supp. IV, 1963).

${ }^{52} 133$ F. Supp. 555 (S.D.N.Y. 1955); 175 id. 230 (1959); 197 id. 755 (1961), af'd and appeal retcined for further proceedings, 317 F.2d 875 (2d Cir. 1963). 
fortunately for our purposes, plaintif in that case ultimately abandoned any claim under the Mutual Security Act and elected to rely solely on the Invention Secrecy Act. ${ }^{53}$ Before it did so, however, certain preliminary matters were decided which are not without interest.

Plaintiff sued the United States under both the Invention Secrecy Act and the Mutual Security Act. In brief, it alleged that it was entitled to compensation because its patent application on a hemispheric gunsight and a vertical periscopic bombsight having been made subject to a secrecy order and issue of a patent having been thereby delayed, the government thereafter induced plaintiff to disclose the invention to another manufacturer, which thereafter used it without adequately compensating plaintiff.

The government first moved to dismiss on the grounds (i) that plaintiff had not exhausted its administrative remedy by seeking a settlement with the head of the military department under the Invention Secrecy Act, and (ii) that plaintiff had lost its rights by disclosing its invention to the other manufacturer. In reply to (ii), plaintiff argued (A) the government had requested this disclosure, (B) such disclosure, having been made under a secrecy agreement, was not a "public disclosure," and (C) plaintiff and the other manufacturer were "in privity" within the meaning of the language of the Mutual Security Act. ${ }^{54}$

The district court ${ }^{55}$ denied the government's motions, ruling:

(i) The possibility of effecting an administrative settlement under the Invention Secrecy Act is not an "administrative remedy" within the meaning of the doctrine of exhaustion of administrative remedies. The plaintiff was therefore free to pursue its statutory remedy in the courts without first seeking a settlement. (Although the court did not discuss the point, it would seem that the same principle would apply to the provisions of the Mutual Security Act (now section 606 of the Foreign Assistance Act) relating to the possibility of administrative settlement).

(ii) The government's other defense, and plaintiff's reply, raised an issue of fact which could not be decided on affidavits on a motion for summary judgment.

In a subsequent decision on the merits ${ }^{56}$ the court reviewed the facts at length, held that plaintiff had met its burden of proving that the invention had been reduced to practice before any royalty-free license to the government had become operative, overruled the government's other defenses, and held that the plaintiff was entitled to reasonable and just compensation for damages under the Invention Secrecy Act.

ه3 66 Stat. 805 (1952), 35 U.S.C. \$\$ I8I-188 (1958).

Es As pointed out above (supra, at 568), $\$ 506(a)$ of the Mutual Security Act of r954, following $\$ 517(2)$ of the 1951 Act, defined "information" to mean "information originated by or peculiarly within the knowledge of the owner thereof and those in privity with him ...." Section $606(2)$ of the rg6r Act omits this privity language. (75 Stat. $44^{\circ}$ (I96r), 22 U.S.C. $\$ 2356$ (a) (Supp. IV, 1963)). Since the latter, however, does not purport to define "information," the omission may not be significant.

t5 133 F. Supp. 555 (S.D.N.Y. 1955).

I75 F. Supp. 230 (S.D.N.Y. I959). 
The court did not, however, decide the amount of such compensation, setting this down for further hearing, as well as the amount of the compensation, if any, due under the Mutual Security Act.

At this point, plaintiff abandoned its claim under the Mutual Security Act and elected to rely solely on its claim under the Invention Secrecy Act. The subsequent proceedings in the case, ${ }^{57}$ although of great interest and although involving an important question of federal jurisdiction, are therefore beyond the scope of this article.

\section{$\mathrm{V}$}

The Weapons Production Program-in General

The Weapons Production Program (WPP) began in December 1957, when the late Secretary of State, John Foster Dulles, offered to make available to other NATO nations American technical knowledge and experience in the manufacture of modern weapons. ${ }^{58}$ As pointed out above, the program now finds its sanction and authority in sections 502 and 503 of the act. ${ }^{59}$

Pursuant to these provisions (or their predecessors), the United States has entered into a series of overall WPP agreements with various NATO countries covering general matters. ${ }^{60}$

The statutes, directives, and regulations of the United States, together with the agreements entered into with our various NATO partners, constitute the legal framework for United States participation in WPP projects. The establishment of these projects, however, starts within NATO. There are committees known as "Groups of Experts," established under the Armaments Committee of NATO as need and interest dictate. These groups consider the latest scientific and engineering advances within their respective spheres of activities.

When it appears that several NATO countries have an unfilled requirement for a given type of weapon, an exchange of information within the cognizant Group of Experts takes place with a view to determining how this need can best be met. It is normally here that a multilateral European production effort under the WPP is first seriously deliberated. If, as a result of these deliberations, sufficient national interest develops, those countries already having in their possession, or under development, weapons of the type needed are called upon to provide information as to the cost, the difficulties, and the patent and other industrial rights involved in the production thereof. Usually the countries having such weapons first make an offer of an outright sale or exchange. It is only if such offer is not forthcoming, or is rejected by the requiring countries, that negotiations leading to a WPP project get under way.

\footnotetext{
${ }^{57}$ I97 F. Supp. 755 (S.D.N.Y. 196r), aff'd and appeal retained for further proceedings, 317 F.2d 875 (2d Cir. I963). See Note, 62 Mrcr. L. REv. 139 (1963).

${ }^{\mathrm{E}}$ See Pasley, supra note 38 , at $95-96$.

${ }^{60}$ Supra, pp. $567-68$.

${ }^{60}$ Pasley, supra note 38 , at 95 . See, e.g., Agreement With France Relating to a Weapons Production Program, Sept. 19, 1960, T.I.A.S. No. 4611, Ir U.S.T. \& O.I.A. 2333 (1960).
} 
From the information furnished by the developing country, the minimum economically feasible production run and the estimated cost per weapon are determined. Firm commitments from each country to purchase the weapons produced are then solicited. Once sufficient commitments are received to make joint production feasible, the participating countries divide the production roughly in the same ratio as the orders placed. Although in this context the United States is not known as a "participating country," it often agrees to buy a share of the end product.

For each project the participating countries set up a Steering Committee, or more usually, an intergovernmental Production Organization, with a board of directors, one director designated by each participating country. Customarily, the United States is not a member of the Production Organization, but rather has its interests protected by a U.S. Special Representative, who sits with the board members but whose vote is limited to those matters which involve United States interests. As to these matters, his vote normally carries with it virtual veto power. ${ }^{61}$

The board of directors (when there is a Production Organization, rather than merely a Steering Committee) establishes a "Management Office," headed by a general manager. The general manager and all key personnel of the program office are selected by the board. The board, after considering the capabilities of each participating nation's contractors makes any adjustments necessary in the allocation of production. The principal contractors in each of the participating countries either create a coordinating superstructure by organizing a new corporation or the coordinating responsibility is assigned to one of the principal contractors. Usually, the participating governments request the NATO Council to designate the Production Organization as a "subsidiary body" of NATO." The program office and the coordinating corporation are normally located in the country which has placed the largest order for the end product and it is usually in that country that final assembly of the weapon takes place. When the weapon being produced is of United States origin, the United States establishes a liaison office at the site of the program office, headed by an officer of the military service having responsibility for the weapon involved in the United States.

When the weapon involved was developed in the United States, a multilateral agreement, known as a "Technical Arrangement," is entered into by and among

"This is the practical effect of various provisions in the "Technical Arrangements," to be discussed below. In the case of the United States, the entire procedure, from the initial consideration by the Groups of Experts to the final production run is monitored by the Defense Representative (DEFREPNAMA) on the staff of the U.S. Mission to NATO and European Regional Organizations (USRO), Paris. The latter official also serves as the Defense Advisor to the United States Ambassador to NATO and the European Regional Organizations.

${ }^{\circ 9}$ Article 9 of the North Atlantic Treaty (T.I.A.S. No. 1964, entered into force August 24, 1949, 63 STAT. 224I, 34 U.N.T.S. 243) establishes a council (now known as the "North Atlantic Council") and authorizes it to "set up such subsidiary bodies as may be necessary." Article I (c) of the Agreement on the Status of the North Atlantic Treaty Organization, National Representatives and International Staff, signed at Ottawa, September 20, I95I (T.I.A.S. No. 2992, 5 U.S.T. \& O.I.A. r087, 200 U.N.T.S. 3), defines the term "subsidiary bodies." Article 4 of this Agreement, read in conjunction with Article I(a), provides that any "subsidiary body" shall possess juridical personality, and shall have the power to conclude contracts, to acquire and dispose of property and to institute legal proceedings. 
the United States, the participating governments, and the Production Organization, covering general matters, including patent rights and technical information, and spelling out the procurement obligations of the United States, if any, and of the participating governments and the amount of assistance which may be furnished by the United States (some of which is on a grant basis and some on a reimbursable basis). When the weapon is of United States origin, the United States at the same times makes a separate arrangement with one or more contractors in the United States for the furnishing of necessary data, technical information, and know-how to the foreign prime contractors. The American contractor conducts negotiations with the national prime contractors concerning the former's privately owned patent rights and know-how involved in the manufacturing of the weapon. There results an agreement, usually between the United States contractor and the European coordinating corporation, under which the former agrees (i) to grant a license under his privately owned rights, (ii) to assist in obtaining a license as to all subcontractor owned rights, and (iii) to furnish a given number of man hours of technical assistance.

In all WPP projects involving American weapons the United States requires that, in return for all American technology furnished (whether government or contractor owned), the United States shall receive a non-exclusive license to practice, or cause to be practiced, all inventions made in the course of the European production, such license to be royalty-free or in some cases on terms no less favorable than those available to the government of any participating country. These so-called "Hlow back" provisions are not liked by the participating countries or, more particularly, by their contractors, but are usually accepted with the understanding that such license does not carry with it a right to use the inventions other than in production of weapons for the use of the United States' own forces.

In general, it may be said that the patent and proprietary rights provisions, and the financial arrangements relating thereto, have been the most complex and difficult to negotiate of all the WPP arrangements, and have presented the greatest number of problems. We propose now to review in greater detail two typical agreements under the WPP relating to patent rights and technical information, and to follow this with a discussion of some of the problems arising from the financial and compensation features thereof.

VI

The Weapons Production Program-Some Typical Arrangements

Several weapons are now being cooperatively produced in Europe under the auspices of NATO. They are "HAWK," a surface-to-air missile, "SIDEWINDER," an air-to-air missile, the F-Io4G Starfighter Jet Aircraft, the Mark 44 Torpedo, "BULLPUP," an air-to-ground missile, and "ATLANTIQUE," a maritime patrol aircraft. All but the latter are of United States origin. Some idea of the 
amounts involved may be obtained from the overall budget estimate for HAWK of $\$ 500,000,000$, and for the F-ro4G of just twice that figure.

Chosen for further discussion here is HAWK, as the first of the WPP programs and as providing the model for those which followed. We propose to review the salient features of

(a) that portion of the Technical Arrangement between the United States and the Production Organization and participating governments as relates to patent rights and technical information;

(b) A licensing agreement between one of the United States contractors ${ }^{63}$ and the European coordinating corporation.

\section{A. The HAWK Program-Technical Arrangements between United States and the Production Organization}

As mentioned above, HAWK is a surface-to-air missile. Of the total monetary amount of about $\$ 500,000,000$ estimated for the project, the United States furnished $\$ 40,000,000$ in grant aid and $\$ 60,000,000$ in reimbursable aid. ${ }^{64}$ Participating governments were Belgium, France, Western Germany, Italy and the Netherlands. The latter established a Production Organization as a "subsidiary body" of NATO. ${ }^{65}$ Each participating government selected a national prime contractor, and the latter organized a coordinating corporation, created under French law, known as "SETEL."

Under the Technical Arrangement entered into between the United States and the Production Organization:

(i) the United States granted to the Production Organization a royalty-free license covering its interest in the subject matter of the project;

(ii) the Production Organization agreed that the United States would be promptly furnished, without cost, all information and data concerning designs, changes, developments, modifications, and improvements in the HAWK system developed by the participating governments, SETEL, the national prime contractors, their subcontractors, or employees, including, whenever legally available, a royalty-free license to use such information or to practice inventions for United States defense purposes throughout the world; if a royaltyfree license was not available, then best efforts would be used to make a license available to the United States at charges no greater than those made to the participating governments, SETEL, and so on, for their own use.

\footnotetext{
os There were two American contractors in the HAWK program.

of Reimbursement of this amount was accomplished by giving a credit to the United States against its obligations under its procurement commitment for the end product. The United States did not necessarily accept delivery of such end items for its own use but would usually furnish them to a friendly foreign nation as a form of military assistance. This somewhat cumbersome procedure, thought necessary at the time because of statutory restrictions, was simplified somewhat in later programs.

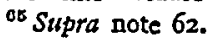


The license from the United States to the Production Organization ((i) above) was elaborated in an Appendix which covered the following points, among others:

(a) The Production Organization would be authorized to use United States government documentation, subject to any rights of private owners of patents or technical information, in accordance with the applicable Patent Interchange Agreements, in the manufacture, use, and disposal of the HAWK system and its derivatives;

(b) With the concurrence of the United States, the Production Organization could authorize such use by SETEL, the national prime contractors, and subcontractors;

(c) If the Production Organization should find it desirable to establish European sources of supply for parts and components, existing commercial arrangements would be used, or new ones established, the United States agreeing to use its good offices to facilitate such arrangements and to assure that they would be fair and equitable.

\section{B. The HAWK Program-Agreements between American Contractors and European Coordinating Corporation}

Certain American contractors, possessed of the necessary "know-how" for the production of the HAWK missile system or its components, entered into agreements with SETEL to make this know-how available to the European producers. Typically, such agreements provided (in the following summary, " $\mathrm{A}$ " refers to the American contractor):

(I) SETEL was granted a nonexclusive, nontransferable license, with a right to sublicense, under $A$ 's patent rights in the participating countries and other NATO countries, and a right to use $A$ 's techniques, in the manufacture and test of the devices involved, subject to certain limitations and qualifications;

(2) The number of devices, manufactured under the foregoing license, to be sold to the United States would be subject to negotiation between the United States and $A$;

(3) Any sublicense by SETEL to others than certain specified participating contractors (called the "Manufacturers") would be subject to $A$ 's consent and United States government approval, and $A$ would receive additional compensation therefor;

(4) $A$ would furnish SETEL and the Manufacturers all relevant technical information, know-how, and other assistance concerning the devices involved and would make available to SETEL and the Manufacturers engineering and technical personnel;

(5) $A$ would, to the extent feasible, sell necessary components to SETEL and the Manufacturers at reasonable prices, or assist them in obtaining the same elsewhere.

For the foregoing (and other services omitted from this summary) SETEL 
agreed to pay $A$ an agreed amount in dollars, plus certain additional fees based on the number of devices sold. In addition, SETEL agreed to reimburse $A$ for its direct costs, and overhead applicable thereto, incurred in furnishing personnel and other services under the agreement. The agreement specifically recited that none of the consideration to be paid by SETEL to $A$ was for rights which the United States government had given, or had the right to give, to SETEL.

The WPP projects which followed HAWK benefited from the experience gained thereunder. The concept of multi-nation management was maintained in all but ATLANTIQUE, but the Production Organization generally took a simpler and more manageable form.

The ATLANTIQUE aircraft was developed in France with multi-nation support, in part with the United States funds provided under both MWDP and the WPP. Management of production is being maintained by France, under a "lead nation" concept of organization which differs from the other WPP projects. The problems of patent rights and proprietary information are somewhat similar but generally simpler as here the developing contractor is also the coordinating corporation. However, the centralization of control in one nation which results under this type of organization has prevented its adoption in other WPP projects.

\section{VII \\ Compensation to American Contractors for License Rights and Technical Information}

In the preceding section, it was explained how arrangements are made for the licensing of patent rights and the furnishing of technical information to the participating countries and their contractors. To enable just this was the chief purpose of the Patent Interchange Agreements. In a sense, it is the heart of the WPP program itself, which was originally envisaged by Secretary Dulles as making available to other NATO countries American know-how and experience so as to equip them with the best possible modern weapons.

When the United States government has full rights to grant such licenses or release such information, no direct compensation is paid by the foreign country or its contractors. (Such furnishing is, of course, a form of grant assistance, to which no dollar figure is assigned). But when the United States government lacks such right, and the furnishing is by or from a private United States contractor, compensation to the latter is expected and demanded, sometimes in amounts which seem to be very substantial.

When the patents or technical information are entirely the result of privately financed enterprise, no objection can be made to the payment of compensation therefor. But when they have grown out of the performance of research and development originally financed under United States government contracts, as is often 
the case, it has been claimed that no further compensation should be paid. ${ }^{00}$ On the one hand, foreign interests have objected to having to pay for such rights and on the other, to the extent that the United States government has participated in the development of a particular invention or device, it has been alleged that it is "paying twice" for the same rights. ${ }^{67}$

In the case of Defense Department research and development contracts, the normal practice has been for the government not to take title to any resulting inventions, but only a license to practice the same for its defense purposes. The argument that the "defense purposes of the United States" includes, in this connection, the military assistance program, or NATO joint production, ran afoul of the rule of the Bofors case, ${ }^{68}$ in which the Court of Claims held that a license to the United States from a Swedish manufacturer to produce its guns "for United States use" did not include production for Lend-Lease purposes.

Nevertheless, because it was felt by some that neither the United States, nor NATO countries or their manufacturers, should have to pay for these rights, the Armed Services Procurement Regulation (ASPR) ${ }^{69}$ has been amended in the following respects:

(I) Paragraph 9-I07. $\mathrm{I}^{70}$ now states that the general policy of the Department of Defense on division of property rights in inventions and discoveries resulting from research work performed under contract is to obtain an irrevocable, nonexclusive, nontransferable "comprehensive license of free use," world-wide in scope, which permits the royalty-free use by the government, government contractors and subcontractors, and "any use by anyone in connection with the performance of a government contract, and any use by anyone in connection with projects funded by the Government, including the Military Assistance Program."

(2) Beginning in March 1960 , the Patent Rights License clause, prescribed for use in military research and development contracts, has included language carrying out the policy set forth above. In June I962, this was further amended to give the government the express "right to grant sublicenses to any foreign government or international organization specifically for use in programs established by International Agreements for research, development or production of weapons or equipment for mutual defense."71 This language goes further than the grant of a royalty-free license for production financed by the United States and includes as well production financed by the participating governments under the WPP.

(3) The Patent Rights License clause further provides, in paragraph (i):

\footnotetext{
${ }^{88}$ See, e.g., Hearings Before a Subcommittee of the Senate Select Committee on Small Business, "Government Procurement 1960: Lack of Competition in Military Procurement and lts Impact on Small Business," 86th Cong., 2 d Sess. $285-89$ (1960).

${ }^{67}$ Ibid.

${ }^{68}$ Aktiebolaget Bofors v. United States, 139 Ct. Cl. 642, 153 F. Supp. 397 (1957).

${ }^{80}$ ASPR, \$IX, "Patents, Data, and Copyrights," 32 C.F.R., Part 9 (196r), as amended (1963 Supp.), 3 CCH Gov't CONT. Rep. IT 33,013-33, 33,064 (1964).

${ }_{70} 32$ C.F.R. ₹ 9.IO7-I (I963 Supp.); 3 CCH Gov'T CONT. REP. I 33,032 (1962).

71 Id. $\$$ 9.107-2(b), sub-clause (b)(x) (Ig63 Supp.); 3 CCH Gov'T CoNT. REP. \$33,033 (Ig63).
} 
The Contractor recognizes that the Government, or a foreign government with funds derived through the Military Assistance Program or otherwise through the United States Government, may contract for property or services with respect to which the vendor may be liable to the Contractor for royalties for the use of a Subject Invention on account of such a contract. The Contractor further recognizes that it is the policy of the Government not to pay in connection with its contracts, or to allow to be paid in connection with contracts made with funds derived through the Military Assistance Program or otherwise through the United States Government, charges for use of patents in which the Government holds a royalty-free license. In recognition of this policy, the Contractor agrees to participate in and make appropriate arrangements for the exclusion of such charges for such contracts or for the refund of amounts received by the Contractor with respect to any charges not so included.

Arguably, this language is limited to production actually paid for by the United States, and does not include production financed by the participating governments, but the phrase "funds derived ... otherwise through the United States government" is at least ambiguous. Moreover, the language of the last two sentences does not seem to be limited to inventions conceived or first reduced to practice in the performance of the particular contract (Subject Inventions) but seems to extend to any patents in which the government holds a royalty-free license.

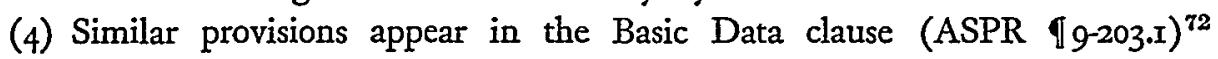
required for use in every contract in which proprietary data is to be delivered, without specific restrictions on its further dissemination. (However, paragraph 9-204.4 provides that where the Department of Defense proposes to make available any data in its possession for use in a foreign country, it shall, to the maximum extent practicable, give reasonable notice to the contractor who furnished it, provided he has previously requested such notice in order to protect his foreign patent position).

(5) Part 3 of section IX of ASPR," entitled "Foreign License and Technical Assistance Agreements," in paragraph 9-301.2, repeats the statement of policy set forth in (3) above with respect to patent licenses and proprietary data, with specific reference to arrangements such as those made under the WPP.

The next paragraph of part 3 (paragraph 9-302) provides that, where the United States government makes a contract with a domestic concern to provide technical assistance or patent rights to a foreign concern or government, the former will not make, "on account of any purchases by the government or by others with funds derived through the Mutual Security Program or otherwise through the government," any charge to the foreign concern or government "(A) for royalties or amortization for patents or inventions in which the government holds a royalty-free license, or (B) for data which the government has a right to possess, use and disclose to others, or (C) for any technical assistance for which the government has paid under a contract" between the government and the domestic concern.

\footnotetext{
72 Id. § 9.203-I (1961), as amended (1963 Supp.); 3 CCH Gov'T CoNr. Rep. I 33,052.10 (1963).

${ }^{78}$ Id. Part 9, Subpart C (1961), as amended, $\S \S 9.304-1,9.304-2$ (1963 Supp.); 3 Gov'T ConT. REP. ใดी $33,061-33,064$ (1964).
} 
Furthermore, in negotiating a price to be paid by the United States government to the domestic concern under any such contract consideration will be given, along with other factors, (a) to the extent to which the government has contributed through past contracts to the development of the supplies or services, or methods of manufacture or performance involved, and (b) to the government's patent rights and rights in proprietary data relating to such supplies, services, or methods of manufacture or performance.

The balance of part three is devoted to further implementation of this policy, including (a) the substance of certain contract provisions which are required in foreign license and technical assistance agreements between domestic concerns and foreign governments or concerns (ASPR 9-304); (b) the required procedure on review by military departments of foreign license and technical assistance agreements between domestic concerns and foreign governments or concerns (ASPR 9-304.2). In substance, if the American concern granting the patent licenses or know-how, to which the government has a royalty-free license or an unrestricted right of user, does not make an appropriate reduction in its fees to reflect United States participation in the financing of the overall program, approval by the United States will be withheld.

It should be made clear that the new policy, extending the scope of the United States government's royalty-free license to include the right to sublicense other governments in connection with international agreements, goes back no further than I960, and has not affected any of the existing WPP arrangements. All existing WPP projects involve weapons developed under contracts let when the pre-existing policies were in effect and thus did not extend to WPP production actually financed by foreign governments. Whatever the defects of these programs may have been, they are not traceable to the previously existing licensing policies, unless indeed one agrees with the critics that the American contractors were not entitled to any further compensation for the licenses and information which they turned over, and considers it a weakness of the program that they were compensated for this.

In a way, the newer policy is a concession, in a limited area, to the theory that the government should take title, rather than a license only, to inventions and discoveries made in the course of government-sponsored research. Debate on this has been endless, and the present authors do not propose to add to the discussion in this article. ${ }^{74}$ However, the new ASPR policy, limited though it is to the military assistance and foreign procurement area, does raise some very real questions of (i) practicality, and (ii) fairness, and it is to these we now turn.

\footnotetext{
74 See, e.g., U.S. Dep't of Justice, Investigation of Government Patent Practices and Policies (1947); Robillard, Government Patent Policy, in Government Contracts and Procurement-Curnent Trends 89 (Southwestern Legal Foundation, Institute on Government Contracts, 1961); Daddario, Patent Policy for a Free Enterprise Economy, 47 A.B.A.J. 671 (196r); Long, A Government Patent Policy to Serve the Public Interest, 47 id. 675 (196r); Keeffe \& Lewis, The Department of Defense Patent Policy at the Cross Roads: An Argument for the Retention of Traditional Incentives, ro CatHouic U. L. REv. 22 (I96I); Symposium, Government Contract Patent Policy, 2I FED. B.J. 3 (Ig6r).
} 


\section{VIII}

\section{Effects of Current United States Policy}

The current United States government policy, as reflected in the revisions to ASPR described in the preceding section, will have a direct effect on any future WPP projects which may be undertaken. It can be expected that this effect will be felt by United States contractors, the government's contracting agencies, NATO and its member countries, the foreign contractors, and the Military Assistance Program itself.

In all the WPP projects involving weapons of United States origin which have been undertaken to date, the American contractor has been called upon to assist in the establishment of a European production line. If the undertaking were to be a success, the American contractor's "know-how" and technical assistance were essential. Putting a fair price on this has been difficult and the subject of extensive negotiations. The United States contractor was understandably reluctant to hand over his technology to a foreign competitor, regardless of price.

In the case of the existing projects, the peg upon which a substantial portion of the American contractor's compensation was based was the fact that he was legally in a position to grant or withhold license rights. It was for this that he was paid an amount sufficient to cause him to reveal his know-how and technology.

With the future loss to the American contractor of the right to grant such licenses, as a result of the latest ASPR revisions, this convenient pricing peg is lost. It can be expected that without it some substitute will have to be found if American contractors are to be induced to part with their technology to foreign competitors. No contractor can be expected to release its "know-how" merely for an amount sufficient to compensate it for the man-hours its technicians spend at European production sites. Unless such substitute is found, two results are almost bound to follow:

(i) Contractors will become increasingly reluctant to accept research and development contracts in the first instance; ${ }^{75}$ and

(ii) They will see no reason for cooperating in joint foreign production, such as is involved in WPP programs.

Their position quite understandably will be that, if the government already has full rights, and they are to receive no further compensation for their "know-how," it is up to the government to transmit the information to foreign countries and their contractors and show the latter how to use it. It is extremely doubtful whether, without the active participation of the developing contractors, this will be possible.

\footnotetext{
${ }^{75}$ However, Admiral Rickover has been quoted as stating that "he has never found an instance where the patent retention provision of the Atomic Energy Act has influenced a company not to undertake Government research and development work, nor has he been aware of any company refusing a Government contract unless it could retain patent rights to any inventions resulting under the contract." Statement on Government Patent Policy, by former Deputy Attorney General Byron R. White, before the Monopoly Subcommittee of the Senate Small Business Committee, March 26, 1962, $6 \mathrm{CCH}$ Gov'r CoNT. REP. qf 80,025 (1963).
} 
It is hardly an answer to say that by accepting the new ASPR clauses, the contractors have agreed to this. It is true that, in so far as such clauses have been accepted, they are presumably valid and enforceable with respect to licenses thereafter granted. The United States contractors' willingness to accept such clauses is due in part to their disadvantageous position in dealing with a government armed with a set of inflexible regulations and standard contract forms and possessed of strong bargaining power, and in part to their realization that the chance of any particular contract resulting in a development which will later become the subject of a WPP project is slight. The fact remains that once full rights are handed over, it is too late to reclaim them later. If a particular invention does become useful in joint European military production, the contractor will have forfeited any right to compensation therefor. Not only that, his bargaining position with respect to possible use of the invention in foreign commercial production is greatly weakened. It should not be surprising then if, asked for his cooperation in future WPP programs, or other international programs of a similar nature, including nonmilitary ones, he may simply refuse.

Nor is it a complete answer to say that the inventions and know-how involved were developed in the course of prior government-sponsored research and development. This argument assumes that reimbursement to a contractor of his costs plus a reasonable fee (most research and development contracts are on a cost-plusfxed-fee basis) is full and fair compensation, not only for the hours of work put in and the physical materials produced, but for the imaginative efforts, the "flash-ofgenius," the mathematical wizardry, the almost superhuman flights of the creative mind, and all the other intangibles which go into the initial creation of a modern scientific device and provide the industrial organization which makes its production possible.

Perhaps in recognition of this, a recent article supporting the thesis that the government should take title to inventions made in the course of governmentsponsored research suggests that "inequities could be eliminated . . . by the government's paying a higher price for the research it requests."78 But this is only to shift the problem to another and less satisfactory ground. If the government is to pay more for its contract research and development, it can only do so by increasing the rate of the fixed fee in all contracts. In the long run this would be more expensive to the government than the old policy of paying the contractor's costs plus a modest fee, and taking a royalty-free license for domestic military use, while recognizing that in an occasional (very occasional) case additional compensation would have to be paid when a particular invention or discovery proved to be useful in a WPP project. Moreover, and this is a more serious objection, once the contractor has been thus compensated at the outset, and has surrendered all his rights, what is the incentive to him subsequently to participate actively in a transfer of such

\footnotetext{
${ }^{78}$ Leontief, On Assignment of Patent Rights on Inventions Made Under Government Research Contracts, 77 HARv. L. Rev. 492, at 497 (1964).
} 
rights and their attendant "know-how" to foreign interests? Ironically, the article just cited admits that a patented invention alone, without its attendant "know-how," is not very useful and that the necessary "know-how" must also be acquired, through learning and experience; initially, it is exclusively in the possession of the developer. ${ }^{77}$ One who would acquire it must learn it from him.

It must be conceded, however, that the current trend is in favor of the government taking title, rather than a mere license, and that the new ASPR policies are only a reflection of this trend in a particular area. Under the Atomic Energy $\mathrm{Act}^{78}$ and the National Aeronautics and Space $\mathrm{Act}^{79}$ the government takes title to all inventions made in the course of government-sponsored research, waiving its right to do so in some areas, and granting back exclusive licenses in some others. ${ }^{80}$ The Department of Justice has recently reiterated its long-standing position in support of the title approach, coupled this time with recognition of the appropriateness of a waiver or license-back in suitable cases. ${ }^{81}$ The Senate Committee on Small Business has come out in favor of the title approach. ${ }^{82}$ Most recently, the late President Kennedy last year promulgated a "Statement of Government Patent Policy" which, while it leaves room for both the title and the license approach, leans heavily toward the former. ${ }^{83}$ Apparently, this Statement of Policy has not yet been fully implemented and the exact form it will take in the Department of Defense is still unknown. But the handwriting is on the wall.

Coming back to the subject matter of this article, it is probably too early to predict the actual results of the new policy on our relationships with the NATO countries and their contractors. Initially, their reaction may well be one of relief that they will no longer have to pay royalties or other charges for a large segment of the patent rights and know-how which are being turned over to them. Admittedly, in the past they have chafed at doing so. Some of their reluctance was traceable to the fear that they might be paying for something they already knew. Some of it was undoubtedly due to a feeling that they were being asked to pay a second time for information for which the American contractor had already been compensated by his own government. However this may be, the participating governments brought pressure on their contractors to agree to pay such compensation (although the amount thereof had to be negotiated in each case) (i) because of

${ }^{27}$ Id. at 496-97.

${ }^{78} 68$ Stat. 944 ( 1954 ), as amended, 42 U.S.C. $\$ 2182$ (Supp. IV, $x_{963}$ ).

${ }^{70} 72$ Stat. 435,42 U.S.C. $\$ 2457$ ( 1958 ).

${ }^{80}$ See, e.g., NASA, Patent Waiver Regulations, and Patent Licensing Regulations, i4 C.F.R., Part 2245 (1963); 5 CCH Gov't Cont. ReP. If 69,10I-69,129 (1962); PoLICY STATEMENT BY ADMINistrator Jasass E. Webb on NASA Patent License and Waiver Regulattons, NASA Release No. 62-228, Oct. 26, 1962, 6 CCH Gov't Cont. Rep. I 80,046 (I962).

${ }^{82}$ Statement on Government Patent Policy, by former Deputy Attorney General Byron R. White, supra note 75.

${ }^{83}$ Select Committee on Small Business, U.S. Senate, I2th Annual Report, May I5, I962, excerpted in $6 \mathrm{CCH}$ Gov'T CONT. REP. I 80,030 (1962).

${ }^{83}$ Government Patent Polict, Memorandum for the Heads of Exectitue Departiments and Agencies, dated Oct. Io, r963, 28 Fed. Reg. I0943 (1963); x CCH Gov'T CoNT. ReP. I 395I (I963). 
reluctance on the part of all concerned to undertake the projects without the assurance of success which the American technical assistance could bring, and (ii) the desire to absorb as much United States advanced technology in as short a time as possible.

Under the new policy this will all be changed. But the initial relief of the foreign contractors and their governments at not having to pay may change to chagrin if they find that the American technology, know-how and assistance are no longer forthcoming.

Legend tells of a fabulous goose which daily laid a golden egg. Everyone knows what happened when its owner became impatient. Is American industry a marvelous bird and its technology a golden egg, one which may be had on reasonable terms but otherwise will not exist? No one knows for certain, but it will be interesting to see whether the United States government's attempt to accommodate its NATO allies under the new ASPR policies has not in fact rendered the golden egg of technology unavailable for future WPP projects. 